\title{
O PAPEL DAS TECNOLOGIAS DE COMUNICAÇÃO EM MANIFESTAÇÕES POPULARES: A “PRIMAVERA ÁRABE" E AS “JORNADAS DE JUNHO" NO BRASIL
}

\section{THE ROLE OF COMMUNICATIONS TECHNOLOGIES IN POPULAR UPRISINGS: THE “ARAB SPRING” AND THE BRAZILIAN “JUNE JOURNEYS”}

\begin{abstract}
RUBENS BEÇAK
Doutor e Mestre em Direito Constitucional e Livre-docente em Teoria Geral do Estado pela Universidade de São Paulo.

Professor Associado da Universidade de São Paulo USP na Faculdade de Direito de Ribeirão Preto (Graduação e Pósgraduação) e na Faculdade de Direito (Pós-graduação). Secretário Geral da Universidade de São Paulo (2010-2014). Professor visitante da Universidad d Salamanca no curso Master en Estudios Brasileños. Coordenador das atividades ligadas ao Termo Aditivo ao Convênio de Colaboração Acadêmica entre a Universidade de São Paulo (USP) e a Universidad de Salamanca (USAL). Presidente Regional da Associação Nacional de Direitos Humanos, Pesquisa e Pós-Graduação (ANDHEP). Líder e Pesquisador do Grupo de Pesquisa: A dimensão ético-moral e o Direito e Pesquisador dos seguintes Grupos de Pesquisa: $O$ Direito à Educação e a Constituição; Núcleo de Pesquisas em Políticas Públicas da Universidade de São Paulo (NUPPs) e $O$ impacto da lei ficha limpa nos tribunais (todos registrados junto ao Diretório dos Grupos de Pesquisa no Brasil do CNPq).
\end{abstract}

rbmerb@gmail.com

JOÃO VICTOR ROZATTI LONGHI

Professor Assistente II DE da Faculdade de Direito da Universidade Federal de Uberlândia. Doutorando em Direito do Estado na Faculdade de Direito da Universidade de São Paulo. Mestre em Direito Civil pela Universidade do Estado do Rio de Janeiro (UERJ). Autor da obra "Propaganda Eleitoral na Internet" (Saraiva, 2014) em coautoria com Auriney Brito e de diversos artigos científicos em obras coletivas dedicadas ao estudo do Direito Eletrônico. Atua como professor convidado em programas de pós-graduação. Foi professor dos cursos de pós-graduação da PUC-Rio, da ESA/OAB-RJ e dos programas executivos do IBMEC-Rio. Foi tutor de pesquisas da Escola de Direito do Rio de Janeiro da Fundação Getúlio Vargas (FGVRio). Bacharel em Direito pela Universidade Estadual Paulista - UNESP. Foi aluno da Universidad de Santiago de Compostela (Espanha), pelo convênio bilateral AREXIORE - UNESP/USC. Foi pesquisador bolsista da Fundação Carlos Chagas Filho de Amparo à Pesquisa do Estado do Rio de Janeiro - FAPERJ, nível mestrado, e da Fundação de Amparo à Pesquisa do Estado de São Paulo (FAPESP), em grau de iniciação científica. joaovrlonghi@yahoo.com.br

\section{RESUMO}

Assevera-se amplamente que o uso maciço das Tecnologias da Informação e Comunicação (TICs) trouxe desdobramentos em todos os setores da sociedade. Entretanto, a questão a despertar interesse científico em ciências sociais aplicadas na contemporaneidade se concentra mais no potencial transformador destas tecnologias do ponto de vista social. Neste contexto se insere este trabalho, que tem por meta averiguar os impacto transformador das manifestações ocorridas no mundo árabe em 2.010 e 2.011, popularmente conhecidas como "primavera árabe", e as ocorridas nos anos de 2.013 em diante no Brasil, chamadas inicialmente de "jornadas de junho". Por meio da pesquisa teórica e bibliográfica, visa-se perquirir acerca do eventual papel de manifestações populares como estas cada vez mais frequentes, rápidas e de pautas diversas, no procedimento de formação da decisão política. Ademais, visa-se também investigar seus limites e desafios para que as reivindicações de tais levantes possam ser levadas em conta no produto final do jogo democrático, qual seja, a lei em sentido amplo.

Palavras-chave: Democracia; Internet; manifestações; primavera árabe; jornadas de junho.

\begin{abstract}
It is widely affirmed that the massive use of information and communication technologies (ICTs) brought developments in all sectors of society. However, the main issue many scientists is the transformative potential of these technologies from the social point of view. This work is part of this context, which aims to ascertain the impacts of the popular movements in the Arab world in 2,010 and 2,011, popularly known as the "Arab spring", and also in the years of 2,013 onwards in Brazil, initially calls "June journeys". Through a theoretical research, the main objective is to assert about the possible role of popular demonstrations as these increasingly frequent, quick and diverse agendas, in the formation of the political decision. Furthermore, the point here is to also investigate their limits and challenges for such uprisings can be taken into account in the final product of the democratic game, which is the Law as a hole.
\end{abstract}

Keywords: Democracy; Internet; Uprisings; Arab Spring; June Journeys; 


\section{SUMÁRIO}

INTRODUÇAO; 1 AS TECNOLOGIAS E A PRIMAVERA ÁRABE; 2 AS MANIFESTAÇÕES POPULARES NO BRASIL; CONCLUSÃO; REFERÊNCIAS.

\section{INTRODUÇÃO}

É senso comum afirmar que a popularização das Tecnologias da Informação e Comunicação (TICS) alterou sensivelmente o cotidiano de todos aqueles que com elas passam a conviver diuturnamente. Afinal, em praticamente todos os campos sociais, políticos, jurídicos, dentre outros, é possível perceber tais transformações.

Não obstante, do ponto de vista científico, as principais controvérsias residem em se saber qual o grau efetivo de transformação social que o uso maciço das tecnologias é capaz de trazer. Em outras palavras, mais especificamente, um dos grandes problemas de pesquisa da atualidade em ciências sociais aplicadas não diz respeito a como computadores, tablets, smartphones e outros dispositivos foram capazes de mudar nossas vidas, mas como nós potencializamos (ou perdemos) a capacidade de alterar a realidade, especialmente a social, através de seu uso.

Este trabalho se insere neste contexto e tem por objeto de estudo os impactos causados por determinadas manifestações populares ocorridas em países do chamado "mundo árabe" em meados de 2010 e 2011 bem como aquelas ocorridas no Brasil, nos anos de 2013 em diante.

Para tal subdivide-se em duas grandes partes.

A primeira disserta brevemente sobre a sucessão de fatos conhecida por primavera árabe, com ênfase em Tunísia e Egito, os dois primeiros países onde eclodiram levantes populares. O recorte de pesquisa é o estudo da utilização e do papel que a Internet e outras tecnologias tiveram na potencialização e concretização dos movimentos que levaram à derrocada dos regimes autoritários ali instalados.

A segunda parte, por sua vez, tem como foco a realidade brasileira. Trata-se da análise das manifestações populares que eclodiram de 2.013, também chamadas por “jornadas de junho", e as posteriores que as sucederam.

Através de uma pesquisa majoritariamente teórica de cunho bibliográfico, visa-se enfrentar o seguinte problema: tais levantes populares, em grande parte arquitetados e concebidos com recurso maciço à tecnologia, têm uma função no processo democrático? A 
hipótese principal é que sim, desdobrando-se em outros questionamentos, tais como quais são seus objetivos, possibilidades, limitações e, eventualmente, em que medida podem contribuir com a decisão política e enriquecer o seu principal produto: a norma jurídica.

\section{AS TECNOLOGIAS E A PRIMAVERA ÁRABE}

0 recente suceder de episódios históricos conhecidos por primavera árabe tem sido analisado por muitos ainda que, como fato histórico, uma compreensão mais profunda e uma análise mais segura careçam de décadas ou mesmo séculos para que seja adequadamente realizada. Não obstante, dada sua importância e, em alguma medida, a surpresa causada em todo mundo pela velocidade com que ocorreram, já há, poucos anos depois, significativa produção científica acerca do tema.

Mark Lynch, por exemplo, assevera que, embora ninguém tenha previsto os levantes no mundo árabe, isso não significa que ninguém os viu chegar. Narra o autor que a chamada primavera árabe começou em dezembro de 2010, mas ganhou seu apogeu no ano seguinte. Não obstante, demonstra que as origens desta desintegração eram visíveis em todos os sistemas políticos, uma vez que o povo de vários países, uma das constantes da região independente do Estado que se analisa, tem sido vítima de manipulação e repressão das mais diversas espécies por parte de seus respectivos regimes. ${ }^{1}$

Do ponto de vista econômico, por sua vez, assevera que as economias não conseguiram criar empregos, especialmente para a população jovem, parte significativa em termos demográficos. Dessa forma, ao passo que crescia o abismo entre ricos e pobres, aumentava a

\footnotetext{
1 Convém menção às palavras originais do autor: "It is commonly said that nobody predicted the upheavals in the Arab world that began in December 2010 and defined the following year. But that does not mean that nobody saw them coming. The crumbling foundations of the Arab order were visible to all who cared to look. Political systems that had opened slightly in the mid-2000s were once again closing down, victim to regime manipulation and repression. Economies failed to produce jobs for an exploding population of young people. As the gap between rich and poor grew, so did corruption and escalating resentment of an out-of-touch and arrogant ruling class. Meanwhile, Islamist movements continued to transform public culture even as Arab regimes used the threat of al-Qaeda to justify harsh security crackdowns." LYNCH, Mark. The Arab uprising: the unfinished revolutions of the middle East. New York: Public Affairs, 2013. p. 11.
} 
corrupção dos grupos estatais e o ressentimento contra uma classe dominante considerada intocável e arrogante. $^{2}$

Finalmente, enquanto isso, os movimentos islâmicos de cunho mais radical continuam a transformar a cultura pública na região e os regimes árabes utilizavam a ameaça da al-Qaeda para justificar a repressão dura por meio de seus aparatos de segurança. ${ }^{3}$

Ou seja, a análise do autor demonstra que há inúmeros fatores políticos, sociais, econômicos e históricos que levaram o mundo árabe a viver a experiência da primavera árabe.

Contudo, restringindo-se ao papel da tecnologia neste processo, salienta Lynch que o acesso à informação e à Internet atuaram como combustíveis das revoluções. Afinal, todas as

\begin{abstract}
${ }^{2}$ Cf. Idem. p. 11-12. Acerca, convém menção às lições do sociólogo Hazem Kandil acerca das condições das classes menos favorecidas no levante egípcio, um dos principais e mais estudados da primavera árabe: "Com relação à distribuição de renda, os trabalhadores fabris estão entre os estratos da classe média baixa da sociedade egípcia, e também se mobilizaram desde o primeiro dia. Não na praça Tahrir, mas em Alexandria, que tem muitas fábricas de grande porte em seus subúrbios, e em diversas cidades do país. Estima-se que a revolta inteira possa ter envolvido algo entre 10 e 15 milhões de pessoas, das quais no máximo 5 milhões no Cairo. Na participação dos operários no movimento, manifestações precederam as greves. Houve uma imensa onda de distúrbios populares pelo país em todo tipo de contexto econômico, desde as cidades de Port Said, Ismaília e Suez, na zona do Canal, até os oásis turísticos do deserto ocidental. Nos oásis de Al-Wahat, onde um hotel de luxo está sendo encravado nas montanhas a um custo enorme e milhões estão sendo gastos em profusas amenidades turísticas, enquanto a população local não recebe praticamente nada, o furor coletivo foi tão intenso que o chefe de polícia da área teve de ser transferido por atirar em manifestantes. Repressão e exploracão foram os fósforos que acenderam o fogo da reacão popular - a repressão afetando os segmentos mais abastados da classe média, e a exploracão os me- nos privilegiados." KANDIL, Hazem. A revolta no Egito. Novos estudos - CEBRAP [online]. 2011, n. 91, pp. 155-193. p. 163-164. Acerca do que chama de subproletariado urbano e os moradores das ashwa'iyyat (algo com favelas), ressalta também certos setores que ficaram alijados deste processo: "Muitos temiam que esses paupérrimos entre os pobres pudessem um dia perpetrar uma jacquerie egípcia. No Cairo e arredores, calcula-se que eles são entre 5 e 6 milhões de pessoas vivendo em condic,ões subumanas habitando favelas sem água encanada, sem energia elétrica, sem rede de esgotos, sem escolas. A palavra árabe para esses lugares é ashwa'iyyat, derivada de uma raiz que significa "ao acaso". Os moradores dos ashwa'iyyat são gente ao acaso: seres humanos contingenciais para aqueles com vida estabilizada, a quem atemorizam como gente completamente destituída que sai de seus habitats sinistros para invadir a cidade ordenada, falando um árabe estranhamente distorcido, procurando emprego desesperadamente, roubando mercadorias e importunando cidadãos para então se recolher a seu mundo de trevas. Eles não poderiam um dia saquear e incendiar a cidade?_Afortunadamente, essa ameaçadora massa humana ficou completamente fora da revolta, o que provavelmente contribuiu para seu caráter civilizado e pacífico. No dia anterior à queda de Mubarak, ativistas de Alexandria estavam planejando convocar esse segmento para engrossar ainda mais os números do movimento. Se tivessem feito isso, sem dúvida teriam espalhado pânico por todo o país. No outro extremo da escala social, a camada realmente rica da sociedade egípcia - a elite dos altos negócios - também não teve, é claro, nenhuma participação no movimento. Essas pessoas, as principais beneficiárias do regime, estavam obviamente por trás de Mubarak e ficaram com os motores de seus jatinhos ligados, prontas para se mandar caso fosse necessário." Id. p. 165. Muitos afirmam que a exclusão destes setores menos abastados do processo revolucionário se deu significantemente pela ausência de acesso à informação.

${ }_{3}$ Cf. LYNCH, Mark. The Arab uprising: the unfinished revolutions of the middle East. New York: Public Affairs, 2013. p. 11.
\end{abstract}


O PAPEL DAS TECNOLOGIAS DE COMUNICAÇÃO EM MANIFESTAÇÕES POPULARES: A “PRIMAVERA ÁRABE” E AS "JORNADAS DE JUNHO" NO BRASIL

RUBENS BEÇAK, JOÃO VICTOR ROZATTI LONGHI

frustrações, independente da orientação política do grupo de onde provinham, ganharam corpo em um ambiente de grande volume informacional: "Talvez os regimes árabes sempre tivessem sido péssimos, incompetentes e corruptos. Mas agora, graças a estações de televisões via satélite como al-Jazeera e à presença da Internet, suas loucuras foram plenamente expostas para um cético público árabe." ${ }^{4}$

E os fatos falam por si. Afinal, sabe-se que a primavera árabe teve origem na Tunísia. 0 estopim foi a história do comerciante de frutas da cidade de Sidi Bouzid, Mohammed Bouazizi. 0 vendedor fora a um conhecido local de comércio ambulante da cidade para trabalhar, prática formalmente proibida, mas amplamente realizada graças ao pagamento de propina às autoridades fiscalizatórias. No dia 17 de dezembro de 2.010, Mohammed não tinha dinheiro para dar às autoridades corruptas, que confiscaram sua mercadoria. Dirigiu-se à municipalidade local para formalizar uma reclamação, onde ninguém the deu ouvidos.

Em sinal de protesto, resolveu incendiar seu próprio corpo e veio a falecer. $O$ ato foi filmado e o vídeo se alastrou pelo Youtube, Facebook, Twitter e outras redes sociais. Em pouco tempo, várias cidade do país estavam imersas em protestos e, em janeiro de 2011 (menos de um mês do início do movimento), o ditador Zine El Abidine Ben Ali foi deposto.

0 ponto de destaque neste e em outros movimentos diz respeito às telecomunicações, especialmente a Internet. Isto porque, a utilização maciça dos meios de comunicação de massa foi responsável pela formação do que Lynch denomina de "nova esfera pública árabe"5 ajudou a fortalecer a identidade árabe para além dos países e não se submetia à censura oficial

\footnotetext{
4 "But now, thanks to satellite televisions stations like al-Jazeera and the spreading presence of the Internet, their follies were on full display to a skeptical Arab public. LYNCH, Mark. The Arab uprising (cit.). p. 14.

${ }^{5}$ Embora o autor se dedique ao estudo dos desdobramentos das revoltas em vários países como uma consequência do fortalecimento de uma esfera pública árabe, em obra anterior, já havia analisado mais detidamente os fatores que levaram a esse fortalecimento. Algo que não necessariamente depende de um ambiente democrático ou de um regime que respeite a liberdade de expressão já que processo de fortalecimento da esfera pública pode ser anterior (ou mesmo independente, em seus termos) da consolidação da democracia: "Such a public sphere cannot be reduced simply to the more generic "public opinion," to the media, or to the infamous "Arab street" that might rise up in fury when sufficiently provoked. An arena of public argument outside the official channels of the state, the public sphere offers a zone of free and critical reason that might influence mass collective action but that cannot be reduced to it. The public sphere does not depend on the existence of democracy-and indeed the emergence of the Arab public sphere can be read as a direct response to the absence of democracy in almost every Arab country, which has led frustrated Arabs to seek out this new space for political argument and debate. Nor, finally, is the public sphere the same as "civil society," the more institutionalized network of social and civic organizations outside of the state." LYNCH, Mark. Voices of the New Arab Public: Iraq, alJazeera, and Middle East Politics Today. New York: Columbia University Press, 2010. p. 59.
} 
de nenhum deles. ${ }^{6}$ E caminha dia após dia para ganhar forma de uma "esfera pública conectada."7 $\mathrm{Na}$ Internet, blogueiros, ativistas sociais e membros de vários setores da população organizaram as manifestações populares e literalmente tomaram as ruas clamando por mudanças. No caso tunisiano, onde grande parte da população tem acesso à tecnologia, o processo ocorreu rapidamente.

Ou seja, ainda segundo Marc Lynch, a ampla disseminação e a utilização das tecnologias reformulou radicalmente o compartilhamento de ideias e opiniões na sociedade árabe. E, ainda que o papel dos meios de comunicação social e da Internet nas revoltas árabes seja superestimado como a causa da revolução, com muita ênfase no Facebook ou Twitter, essa mudança geracional e estrutural na natureza da comunicação política representou algo fundamental e significativo. ${ }^{8}$

\footnotetext{
${ }^{6} \mathrm{O}$ autor atribui grande parte do que ocorrera à rede de televisão fechada al-Jazeera, que também contribuiu para fortalecer a esfera pública árabe, além, é claro, da Internet: All of these frustrations festered at a time of radical, revolutionary change in the information environment. Perhaps the Arab regimes had always been bickering, incompetent, corrupt. But now, thanks to satellite televisions stations like al-Jazeera and the spreading presence of the Internet, their follies were on full display to a skeptical Arab public. Arab leaders could no longer go about their business in private while crushing any sign of discontent. Their people now had access to information and an ability to express their opinions publicly far beyond anything the region had ever before known. When Mohammed Bouazizi set himself on fire in Sidi Bouzid in protest over abusive police on December 17, 2010, the Arab world was ready to respond. I have been deeply immersed in the evolution of what I call a "new Arab public sphere" for well over a decade. My 2006 book Voices of the New Arab Public had focused on al-Jazeera and the satellite television revolution that had shattered the Arab regimes' ability to control the flow of information or the expression of opinion. Most of my academic writings have focused on the impact of new communications technologies and their effects on political and social action. I had written about Egyptian bloggers and their political activism, as well as how Internet activism was changing the perspectives of young members of the Muslim Brotherhood. I had written about how al-Qaeda and radical Islamists used the new media, including Internet forums, to spread their narratives and their propaganda. I had written about al-Jazeera's talk shows and news coverage, and how they spread both a pan-Arabist identity and a political orientation highly critical of the authoritarian status quo. All of these writings pointed toward the evolution of a new public sphere that would inevitably challenge the pillars of Arab authoritarian domination.

${ }^{7}$ Acerca do conceito de esfera pública conectada, V. BENKLER, Yochai. The wealth of networks: how social production transforms markets and freedom. New Heaven: Yale University Press, 2003. p. 214 e ss. Para uma análise da Internet como esfera pública em diálogo com as instituições oficiais, V. BEÇAK, Rubens; LONGHI, João Victor Rozatti. Internet como esfera pública global e o papel atual dos parlamentos no processo legislativo. in Revista de Cultura e Extensão da USP, São Paulo, n. 13, p. 43-53, maio 2015 DOI: http://dx.doi.org/10.11606/issn.2316-9060.v13i0p43-53. Acesso em: 15 set. 2015.

${ }^{8}$ Menção obrigatória ao original: "The transformation that led to the Arab uprising starts with new information and communications technologies, including satellite television, the Internet, and cheap mobile phones. The widespread dissemination and use of such technology has radically reshaped the way information, ideas, and opinions flow through Arab society. The role of social media and the Internet in the Arab uprisings has often been exaggerated, with too much emphasis on Facebook or Twitter rather than on the underlying political struggles. But this generational, structural change in the nature of political communication represents the most fundamental and significant real effect of these new
} 
0 autor ainda destaca o que seriam os três efeitos da formação desta nova esfera pública no mundo árabe: 1 . Um fluxo mais livre de informações e um fortalecimento do debate público que rompeu com a habilidade dos regimes árabes autoritários de controlar o fluxo de ideias e para impor a conformidade pública; 2. Um empoderamento de ativistas e cidadãos comuns, dando-lhe novas competências, habilidades e possibilitando a criação de novas expectativas, tais como operar dentro de um ambiente de informação radicalmente novo, em povos que esperam coisas diferentes de seus Estados e sociedades e são capazes de reivindicálas de maneiras novas; 3. Uma unificação do espaço político árabe, reunindo todas as questões regionais em uma narrativa comum, remodelando uma nova esfera pública árabe altamente crítica da maioria dos regimes e extremamente pan-arabista em sua orientação, além de consciente do poder das ruas árabes, por muito tempo relegado a segundo plano. ${ }^{9}$

Por sua vez, outro país onde a primavera árabe derrubou seu regime foi no Egito, conforme já salientado, um dos casos mais analisados. Entretanto, a população egípcia, mais heterogênea do ponto de vista social, cultural e econômico, no que concerne especificamente ao acesso à Internet, não tinha amplo acesso a essas tecnologias como no caso tunisiano. Daí porque haver quem questione acerca do protagonismo das tecnologias no processo de revolução egípcia.

Porém, explica Arlene Clemesha que a tecnologia foi importante, mas não por si só. Ou seja, o uso das TICs foi decisivo "em aliança aos movimentos sociais e dos trabalhadores que há anos vinham realizando manifestações e enfrentando uma brutal repressão da polícia egípcia”. ${ }^{10}$

media" Cf. LYNCH, Mark. The Arab uprising: the unfinished revolutions of the middle East. New York: Public Affairs, 2013. p. 22.

9 In verbis: "There were three great effects of this new media environment. First, the free flow of information and the explosion of public discourse and open debate have shattered one of the core pillars of the authoritarian Arab systems that evolved over the 1970s and 1980s: their ability to control the flow of ideas and to enforce public conformity. Second, it has given today's activists and ordinary citizens new skills, expectations, and abilities. They operate within a radically new information environment, expect different things from their states and societies, and are able to act in new ways to demand them. Finally, it has unified the Arab political space, bringing together all regional issues into a common narrative of a shared fate and struggle. This new Arab public sphere is highly critical of most ruling regimes, extremely pan-Arabist in its orientation, and self-consciously celebratory of the power of a long-denied Arab street." Cf. LYNCH, Mark. The Arab uprising: the unfinished revolutions of the middle East. New York: Public Affairs, 2013. p. 22-23.

${ }^{10} \mathrm{Cf}$. NASCIMENTO, Paulo Cesar. Déspotas em retirada: entrevista com Arlene Clemesha, Mohamed Habib e Reginaldo Nasser, in Jornal da Unicampi. Campinas, 14 a 20 de março de 2011 - ANO XXV - № 486. p. 67. Disponível em : http://www.unicamp.br/unicamp/unicamp_hoje/ju/marco2011/ju486_pag05.php. Acesso em: 01 out. 2015. E complementa asseverando que "as redes sociais eletrônicas devem manter um papel importante, mas que as populações do Egito e da Tunísia -- além dos demais países onde a 
Em igual medida, Marc Lynch, para quem a tecnologia foi crucial, dentre outros fatores: "A revolta teria sido impossível sem fatores como a mudança geracional, novas tecnologias, liderança americana e o regional equilíbrio de poder militar, todos trabalhando juntos." 11 Opinião corroborada pelas lições de Manuel Castells, em obra dedicada à primavera árabe e outros movimentos semelhantes, inclusive no Brasil, os quais denominam de "Redes de indignação e esperança":

O papel da Internet e da comunicação sem fio nos atuais movimentos sociais em rede é fundamental, como está documentado neste livro. Mas a compreensão delas tem sido obscurecida por um debate sem sentido, na mídia e nos círculos acadêmicos, ao negar que as tecnologias de comunicação estejam na raiz dos movimentos sociais. Isso é óbvio. Nem a internet nem qualquer outra tecnologia, nesse sentido, podem ser fonte de causação social. Os movimentos sociais surgem da contradição e dos conflitos de sociedades específicas, e expressam as revoltas e os projetos das pessoas resultantes de sua experiência multidimensional.

Ao mesmo tempo, porém, é essencial enfatizar o papel basilar da comunicação na formação e na prática dos movimentos sociais, agora e ao longo da história. ${ }^{12}$

Portanto, é possível extrair duas conclusões da análise da primavera árabe: 1. A tecnologia é essencial, mas não é causa e sim instrumento para o empoderamento da população; 2. Não é possível afirmar com segurança que a consequência natural deste processo é o aprofundamento da democracia.

É o que destaca Ashraf El-Sharif, para quem o "futuro próximo do Egito é desolador. Em muitos aspectos, o Estado voltará para onde foi em 2011, quando os revolucionários tomaram as ruas para derrubar o regime de Mubarak." ${ }^{13}$ Em tom semelhante,

derrubada de regimes opressores foi posta na ordem do dia -, vão precisar de bem mais do que redes como o Facebook para organizar a continuidade da revolução a partir de agora." Idem.

11 "The uprising would have been impossible without factors like generational change, new technologies, American leadership, and the regional military balance of power, all working together." LYNCH, Mark. The Arab uprising: the unfinished revolutions of the middle East. New York: Public Affairs, 2013. p. 16.

12 CASTELLS, Manuel. Redes de indignação e esperança. Trad. Carlos Alberto Medeiros. Rio de Janeiro: Zahar, 2013. p. 134.

${ }_{13}$ In verbis: "Egypt's near future is bleak. In many ways, the state is back to where it was in 2011, when revolutionaries took to the streets to take down the Mubarak regime." 0 autor inclusive profetiza o que ocorreria no país após a ascensão e queda da autoridade muçulmana no poder e o retorno a um regime militar do presidente Abdul Fatah Khalil Al-Sisi, que para muitos fez o país retornar a algo muito semelhante ao do antigo ditador Hosni Mubarak: "Authoritarian forces-the military, the Muslim Brothers, the old state bureaucracy, and business interest groups-remain the key political players. The military in particular is assuming more and more dominance. The personality cult of the popular General el-Sisi shaped by the media hailing him as the "savior and leader of the nation" raises fears about a possible dictatorship in the making. The military institution's appetite for appropriating economic assets and 
O PAPEL DAS TECNOLOGIAS DE COMUNICAÇÃO EM MANIFESTAÇÕES POPULARES: A “PRIMAVERA ÁRABE” E AS "JORNADAS DE JUNHO" NO BRASIL

RUBENS BEÇAK, JOÃO VICTOR ROZATTI LONGHI

Bruce K. Rutherford, para quem a transição para a democracia não é provável em nenhum regime do mundo árabe. No entanto, uma reversão ao autoritarismo completo seria igualmente improvável, já que a transição para a democracia (se é que ocorrerá), passa pela formação do que chama de regimes híbridos, com características autoritárias, mas, em certa medida, estruturas próprias de estados democráticos. ${ }^{14}$

Logo, ainda que haja a formação destes regimes híbridos, uns mais outros menos autoritários, parece prevalecer a conclusão de Marc Lynch sobre o que exatamente são os levantes árabes: eles não necessariamente são movimentos de democratização. Na visão do autor, seus produtos serão novas democracias, novas ditaduras, monarquias reformadas, eventualmente novos Estados e algumas guerras civis. ${ }^{15}$

Eis o que explica tanto o desfecho tunisiano, com uma nova Constituição, como as guerras civis na Líbia ${ }^{16}$ e na Síria, que têm produzido milhões de refugiados e parece longe de um fim. Isto sem contar o fortalecimento de grupos como o Estado Islâmico, que tem contribuído

investments is also alarming. [...] This precarious situation has implications beyond Egypt's borders as well. The crisis undercuts the prevailing idea in the West that conservative, benign, procedural democracies led by moderate Islamists and old state institutions in the Arab Spring countries can produce stable electoralist regimes. The Arab Spring will not become an Islamist winter, but it will also not realize its dreams and democratic potential any time soon. Fully consolidated counterrevolution will not be the outcome either." EL-SHERIF, Ashraf. Egypt Post-Mubarak predicament. in Carnegie Endowment for International Peace. Carnegie Endowment for International Peace Publications Department : Washington (DC), 2014. p. 36.

${ }^{14}$ Convém menção ao original, A full transition to democracy is not likely in any contemporary Arab regime. However, for regimes with these hybrid characteristics, a reversion to full authoritarianism is equally unlikely. In order to understand the future of democracy in the Arab world, we need to understand how these hybrid regimes emerge, why they remain stable, and whether they will transition toward democracy. RUTHERFORD, Bruce K. Egypt after Mubarak: Liberalism, Islam, and Democracy in the Arab World: Liberalism, Islam, and Democracy in the Arab World. Princeton: Princeton University Press, 2013. p. 97. Interessante ressaltar que, em alguns Estados, é possível notar a presença de reformas, ainda que tímidas, em alguns casos. Na Tunísia, onde tudo começou, há uma nova Constituição vigente, que adota um sistema parlamentarista e mesmo em países institucionalmente fechados ao ideário ocidental no plano político, como é o caso da Arábia Saudita, criou-se a possibilidade de mulheres participarem das eleições municipais.

${ }^{15}$ In verbis: "What are the Arab uprisings? Clearly the events of 2011 in the Middle East are not yet a story of democratic transitions. Nor are they yet clearly revolutions. Arab Spring-a term that I may have unintentionally coined in a January 6, 2011, article-does not do justice to the nature of the change. The uprisings are an exceptionally rapid, intense, and nearly simultaneous explosion of popular protest across an Arab world united by a shared transnational media and bound by a common identity. Those uprisings are playing out very differently across the region and are likely to produce new, very mixed regional politics-some new democracies, some retrenched dictatorships, some reformed monarchies, some collapsed states, and some civil wars." LYNCH, Mark. The Arab uprising: the unfinished revolutions of the middle East. New York: Public Affairs, 2013. p. 20.

${ }^{16}$ Nesse sentido, V. PRASHAD, Vijay. Arab Spring, Libyan Winter. Baltimore: AK Press Publishing \& Distribution, 2012. passim 
fortemente para a instabilidade na região. ${ }^{17}$ Razão pela qual a primavera árabe traz lições importantes sobre o uso das Tecnologias como instrumento de manifestação política, mas não há consenso sobre qual o rumo e o que pode ser extraído no evolver rumo a um aprofundamento dos mecanismos democráticos.

\section{AS MANIFESTAÇÕES POPULARES NO BRASIL}

Vistos brevemente alguns aspectos da primavera árabe, analisa-se a realidade dos levantes populares no Brasil ocorridos após 2.013 e a influência das Tecnologias no aprimoramento do processo democrático.

Preliminarmente, é necessário salientar que as chamadas jornadas de junho de 2.013 parecem diferir sensivelmente das manifestações que as sucederam, especialmente aquelas ocorridas após a reeleição da presidente Dilma Rousseff em 2014. Embora as pautas sejam difusas, o sistema de organização usa maciçamente das redes sociais na Internet.

Além disso, deve-se também ressaltar que, embora relativamente recentes do ponto de vista histórico, há alguma produção científica acerca dos levantes brasileiros. Ainda que pouco conclusivas $^{18}$ e que, em grande medida, superestimaram o potencial transformador dos movimentos.

Uma das leituras mais influentes é aquela feita por Manuel Castells. Conhecido pelo tom otimista ${ }^{19}$ com que se debruça sobre os fenômenos relacionados à sociedade da informação, o

\footnotetext{
${ }^{17}$ É a tese de Mark A. Gabriel, para quem a primavera árabe é a raiz do que chama de inverno ISIS (sigla que significa Estado Islâmico): "HOW THE ARAB SPRING TURNED TO AN ISIS WINTER. IN THIS CHAPTER I will explain how the hope of the Arab Spring resulted in a new level of Islamic extremism as radicals took advantage of a vacuum in leadership to gain new ground for their cause." GABRIEL, Mark A. Islam and Terrorism: The Truth About ISIS, the Middle East and Islamic Jihad. 2. ed. Crishma House: Florida, 2015. p. 21. Grifos no original.

18 Embora com profunda análise teórica acerca do tema,ainda parece dificil concluir qual seria a contribuição efetiva dos movimentos do ponto de vista empírico. Cf. CARNEIRO, Thiago Lopes. DA "IMOBILIDADE" À AÇÃO: POR QUE OS BRASILEIROS SAÍRAM ÀS RUAS EM JUNHO DE 2013? O CONTÁGIO COMPORTAMENTAL COMO PARTE DA EXPLICAÇÃO. E-Legis - Revista Eletrônica do Programa de PósGraduação da Câmara dos Deputados, [S.l.], p. 26-45, ago. 2014. ISSN 2175-0688. Disponível em: <http://e-legis.camara.leg.br/cefor/index.php/e-legis/article/view/185/228>. Acesso em: 06 Out. 2015. p. 39

19 Eduardo Magrani traça a distinção entre corrente otimista e corrente pessimista da democracia eletrônica. Cf. MAGRANI, Eduardo. Democracia conectada: a Internet como ferramenta de engajamento politico-democrático. Curitiba: Juruá, 2014. p. 100 e ss. Embora a denominação pareça ser superficial, haja vista que os "pessimistas da Internet" são muitos e abordam o tema sob inúmeras vertentes, Magrani elenca, dentre outros, Tim Wu (V. WU, Tim. Impérios da comunicação. Do telefone à internet, da AT\&T ao
} 
autor dedicou sua análise também à realidade brasileira quando disserta sobre as redes de indignação e esperança que tomaram vários países do mundo nos últimos anos. ${ }^{20}$

Inicialmente, enfatiza o papel do chamado movimento Passe livre, que protestava contra o aumento de vinte centavos nas passagens de ônibus na cidade de São Paulo. Contudo, combinado com uma série de fatores, tais como a proximidade com a Copa das Confederações FIFA 2.013, evento teste para a Copa do Mundo FIFA de Futebol que se realizou em 2.014, o movimento ganhou rápida adesão de inúmeros setores da sociedade, ${ }^{21}$ reunindo milhões de pessoas em mais de 350 cidades ao longo do país.

Conforme destaca, um dos famosos lemas das manifestações fora "não são só vinte centavos, são nossos direitos". ${ }^{22}$ Segundo Castells, o alvo dos manifestantes era a tradicional forma de se fazer política, a dinâmica anacrônica com que os sistemas democráticos se estruturam e funcionam, o distanciamento entre instituições políticas e cidadãos e, para diferenciar o caso brasileiro, a distorção causada pelo uso político de megaeventos esportivos, com intervenções urbanas cosméticas que atendem a interesses especulativos e não nas reais

Google. Trad. Cláudio Carina. Rio de Janeiro: Zahar, 2012.), Eli Pariser, (V. PARISER, Eli. O filtro invisível. 0 que a Internet está escondendo de você. Trad. Diego Alfaro. Rio de Janeiro: Zahar, 2012), Cass Sunstein ( V. SUNSTEIN, Cass. Republic.com 2.0. Princeton: Princeton University Press, 2007.), Evgeny Morozov (V. MOROZOV, Evgeny. The net desilusion: the dark side of network freedom. New York: Public Affairs, 2011.) A distinção entre "pessimistas" e "otimistas" é utilizada também por Marciele Merger Bernardes. Dentre os primeiros, Marciele elenca Lawrence Lessig (V. LESSIG, Lawrence. Code: version 2.0. 2. ed. New York: Basic Books, 2006.) e Perez Luño (V. PEREZ LUÑO, António. ¿Ciberciudadanía o ciudadanía.com? Barcelona: Gedisa, 2004.). Dentre os segundos, destaca Manuel Castells (V. CASTELLS, Manuel. La galaxia Internet. Trad. Raúl Quintana. Barcelona: Aretè, 2001.) e Pierre Levy (V. LEMOS, André; LEVY, Pierre. O futuro da Internet: em direção a uma ciberdemocracia planetária. São Paulo: Paulus, 2010.). Cf. BERNARDES, Maciele Berger. Democracia na Sociedade Informacional: o desenvolvimento da democracia digital nos municípios brasileiros. São Paulo: Saraiva, 2013. p. 45 e ss.

Entretanto, em que pese parecer ser didática a distinção apresentada, prefere-se para fins deste trabalho a análise pontual dos principais problemas para a realização satisfatória dos potenciais da Internet levantados por eles haja vista não ser aqui um objetivo classificá-los.

${ }^{20} \mathrm{Cf}$. CASTELLS, Manuel. Redes de indignação e esperança. Trad. Carlos Alberto Medeiros. Rio de Janeiro: Zahar, 2013. Pósfácio à edição brasileira. p. 144 e ss.

${ }^{21}$ A heterogeneidade dos manifestantes não é pacífica. Explica Andre Singer, por exemplo, que o perfil dos manifestantes em junho de 2.013, seria do que denomina de "novo proletariado", representado pelos trabalhadores jovens que conquistaram trabalho no Mercado formal na década de 2002-2012. 0 autor corrobora a assertive por análise quantitativa. Cf. SINGER, André. Brasil, junho de 2013, classes e ideologias cruzadas. Novos estud. - CEBRAP, São Paulo, n. 97, p. 23-40, Nov. 2013 . Available from <http://www.scielo.br/scielo.php?script=sci_arttext\&pid=S0101-33002013000300003\&lng=en\&nrm=iso>. access on 06 Oct. 2015.

22 CASTELLS, Manuel. Redes de indignação e esperança. Trad. Carlos Alberto Medeiros. Rio de Janeiro: Zahar, 2013. Pósfácio à edição brasileira. p. 145. 
necessidades da maior parte dos que sempre foram excluídos do pleno gozo do direito à cidade. ${ }^{23}$

Sobre o papel da Tecnologia, Castells se mantem fiel às suas premissas ao asseverar que a cada dia a comunicação promove o "empoderamento dos cidadãos, sua autonomia comunicativa e a consciência dos jovens de que tudo que sabemos do futuro é que eles o farão. Mobilizados."24

Mas Manuel Castells asseverou à época que o diferencial do caso brasileiro foi a resposta do governo, que prontamente veio a público dizer que estava atento às ruas, propondo uma série de mudanças. E o Congresso, por seu turno, considerado "grotesco" pelo autor pela tendência de aprovar a PEC 37, que visava impedir o Ministério Público de investigar crimes, teve de dar meia volta e rejeitar rapidamente a proposta. ${ }^{25}$

Ainda que este tenha sido um dos “desfechos" das manifestações, trata-se de um resultado que fica muito aquém do que se reivindicou por parte dos manifestantes e, principalmente, que se revelou, mutatis mutandi, tão frustrante quanto em alguns países do mundo árabe quando comparada às expectativas esboçadas pela comunidade acadêmica ${ }^{26}$ sobre um possível processo incipiente de aprimoramento institucional no Brasil. ${ }^{27}$

${ }^{23}$ Convém menção às palavras do autor: "De forma confusa, raivosa e otimista, foi surgindo por sua vez essa consciência de milhares de pessoas que eram ao mesmo tempo indivíduos e um coletivo, pois estavam - e estão - sempre conectadas, conectadas em rede e enredadas na rua, mão a mão, tuites a tuites, post a post, imagem a imagem. Um mundo de virtualidade real e realidade multimodal, um mundo novo que já não é novo, mas que as gerações mais jovens vem como seu. Um mundo que a gerontocracia dominante não entende, não conhece e que não lhe interessa, por ela encarado com suspeita quando seus próprios filhos e netos se comunicam pela internet, entre si e com o mundo, e ela sente que está perdendo o controle." CASTELLS, Manuel. Redes de indignação e esperança. Trad. Carlos Alberto Medeiros. Rio de Janeiro: Zahar, 2013. Pósfácio à edição brasileira.. p. 145.

${ }^{24}$ Este é o termo usado por David Harvey, considerado “inalienável” por ser um desdobramento do direito à liberdade. Cf. HARVEY, David. A liberdade da cidade. in MARICATO, Ermínio et alli . Cidades rebeldes Passe Livre e as manifestações que tomaram as ruas no Brasil. São Paulo: Boitempo/Carta Maior, 2013. p. 34.

${ }^{25}$ CASTELLS, Manuel. Redes de indignação e esperança. Trad. Carlos Alberto Medeiros. Rio de Janeiro: Zahar, 2013. Pósfácio à edição brasileira. p. 146.

${ }^{26}$ Sintetizando tais expectativa, Ricardo Antunes e Ruy Braga, que ressaltam o descompasso entre o Congresso e os pleitos. Ao passo que os manifestantes esboçavam (ao começo) pleitos progressistas, o Congresso votava a "Cura Gay". Cf. ANTUNES, Ricardo; BRAGA, Ruy. Os dias que abalaram o Brasil: as rebeliões de junho, julho de 2013 in Revista de políticas Públicas: programa de pós graduação em políticas públicas da Universidade Federal do Maranhão. v. 18, n. 2 (2014).

${ }^{27}$ Embora a maioria dos pleitos não tenha sido atendido, uma reivindicação à época era a da realização de uma reforma política cujos principais pontos a serem alterados seria a vedação de doações de pessoas jurídicas de direito privada para partidos ou candidatos para fins eleitorais. Embora não tenha advindo do Parlamento tal transformação, o Supremo Tribunal Federal, no julgamento da ADI 4650, considerou inconstitucional tal prática. In verbis, o Informativo $n^{\circ}$ 799: "São inconstitucionais as contribuições de pessoas jurídicas às campanhas eleitorais. No que se refere às contribuições de pessoas físicas, regulam-se 
de acordo com a lei em vigor. Esse o entendimento do Plenário, que, em conclusão de julgamento e por maioria, acolheu, em parte, pedido formulado em ação direta para declarar a inconstitucionalidade dos artigos 23, $\$ 1^{\circ}$, I e II; 24; e 81, "caput" e $\$ 1^{\circ}$, da Lei 9.504/1997 (Lei das Eleições), que tratam de doações a campanhas eleitorais por pessoas físicas e jurídicas, no ponto em que cuidam de doações por pessoas jurídicas. Declarou, ainda, a inconstitucionalidade dos artigos $31 ; 38$, III; 39, "caput" e $\S 5^{\circ}$, da Lei 9.096/1995 (Lei Orgânica dos Partidos Políticos), que regulam a forma e os limites em que serão efetivadas as doações aos partidos políticos, também exclusivamente no que diz respeito às doações feitas por pessoas jurídicas - v. Informativos 732 e 741. O Colegiado reputou que o modelo de autorização de doações em campanhas eleitorais por pessoa jurídica não se mostraria adequado ao regime democrático em geral e à cidadania, em particular. Ressalvou que o exercício de cidadania, em sentido estrito, pressuporia três modalidades de atuação física: o "jus sufragius", que seria o direito de votar; o "jus honorum", que seria o direito de ser votado; e o direito de influir na formação da vontade política por meio de instrumentos de democracia direta como o plebiscito, o referendo e a iniciativa popular de leis. Destacou que essas modalidades seriam inerentes às pessoas naturais e, por isso, o desarrazoado de sua extensão às pessoas jurídicas. A participação de pessoas jurídicas apenas encareceria o processo eleitoral sem oferecer, como contrapartida, a melhora e o aperfeiçoamento do debate. 0 aumento dos custos de campanhas não corresponderia ao aprimoramento do processo político, com a pretendida veiculação de ideias e de projetos pelos candidatos. Ao contrário, os candidatos que tivessem despendido maiores recursos em suas campanhas possuiriam maior êxito nas eleições. Ademais, a exclusão das doações por pessoas jurídicas não teria efeito adverso sobre a arrecadação dos fundos por parte dos candidatos aos cargos políticos. Todos os partidos políticos teriam acesso ao fundo partidário e à propaganda eleitoral gratuita nos veículos de comunicação, a proporcionar aos candidatos e as suas legendas, meios suficientes para promoverem suas campanhas. 0 princípio da liberdade de expressão, no aspecto político, teria como finalidade estimular a ampliação do debate público, a permitir que os indivíduos conhecessem diferentes plataformas e projetos políticos. A excessiva participação do poder econômico no processo político desequilibraria a competição eleitoral, a igualdade política entre candidatos, de modo a repercutir na formação do quadro representativo. Assim, em um ambiente cujo êxito dependesse mais dos recursos despendidos em campanhas do que das plataformas políticas, seria de se presumir que considerável parcela da população ficasse desestimulada a disputar os pleitos eleitorais. [...] Tribunal, com relação aos mecanismos de controle dos financiamentos de campanha, rechaçou a afirmação no sentido de que a discussão acerca da doação por pessoa jurídica deveria se restringir aos instrumentos de fiscalização. Defender que a questão da doação por pessoa jurídica se restrinja aos mecanismos de controle e transparência dos gastos seria insuficiente para amainar o cenário em que o poder político mostrar-se-ia atraído pelo poder econômico. A possibilidade de que as empresas continuassem a investir elevadas quantias - não contabilizadas (caixa dois) - nas campanhas eleitorais não constituiria empecilho para que o STF declarasse ser disfuncional o corrente modelo. Assinalou a inconstitucionalidade dos critérios de doação a campanhas por pessoas jurídicas, sob o enfoque da isonomia entre elas, haja vista que o art. 24 da Lei das Eleições não estende essa faculdade a toda espécie de pessoa jurídica. 0 aludido preceito estabelece rol de entidades que não poderiam realizar doações em dinheiro ou estimáveis em dinheiro a candidatos ou a partidos políticos, a exemplo das associações de classe e sindicais, bem como entidades integrantes do terceiro setor. Como resultado desse impedimento, as empresas privadas - cuja maioria se destina à atividade lucrativa - seriam as protagonistas em doações entre as pessoas jurídicas, em detrimento das entidades sem fins lucrativos e dos sindicatos, a desaguar em ausência de equiparação entre elas. Vencidos os Ministros Teori Zavascki, Gilmar Mendes e Celso de Mello, que julgavam parcialmente procedente o pleito, para dar interpretação conforme à Constituição às normas impugnadas e vedar as seguintes formas de contribuição a partidos políticos e a campanhas eleitorais: a) de pessoas jurídicas ou de suas controladas e coligadas que mantivessem contratos onerosos celebrados com a Administração Pública, independente de sua forma e objeto; b) de pessoas jurídicas a partidos (ou seus candidatos) diferentes, que competem entre eles. De igual forma, proibiam que pessoas jurídicas que tivessem efetuado contribuições a partidos ou campanhas, desde então e até o término da gestão subsequente, celebrassem qualquer contrato oneroso com entidades da Administração. Por fim, o Colegiado deliberou não modular os efeitos da decisão, tendo em vista não haver sido atingido o número 
As urnas, a seu turno, também não parecem ter refletido os anseios das ruas. Pouco se alterou no que concerne ao perfil da representação política, produzindo um Congresso cada dia mais preocupado com seus próprios interesses e refratário a iniciativas que proponham um repensar da democracia em prol do aprofundamento dos mecanismos de participação. ${ }^{28}$ Especialmente com recurso às Tecnologias da Informação e Comunicação. ${ }^{29}$

\section{CONCLUSÃO}

É comum o recurso à definição de Norberto Bobbio de que Democracia é o respeito às regras do jogo. ${ }^{30}$ Ao mesmo passo que, dentre as várias correntes contemporâneas sobre democracia deliberativa, chama atenção a ideia de que as regras se arquitetam em um processo democrático, cujos procedimentos têm por fim a busca de um consenso possível. ${ }^{31}$

Evidente, portanto, que levantes populares como os analisados neste trabalho têm sua função no processo democrático. Afinal, quando milhões de pessoas saem às ruas para demonstrar insatisfações das mais diversas, por mais difusas que sejam, parece claro que o sistema proposto para sintetizar os pleitos na democracia representativa dá sinais de

necessário de votos para tanto. Assim, a decisão aplicar-se-á a partir das eleições de 2016, inclusive, independentemente da publicação do acórdão." ADI 4650/DF, rel. Min. Luiz Fux, 16 e 17.9.2015. (ADI4650)" A íntegra do acórdão ainda não foi divulgada.

28 Para maiores aprofundamentos sobre o princípio democrático em perspectiva histórico evolutiva, BEÇAK, Rubens. Democracia: hegemonia e aperfeiçoamento. São Paulo: Saraiva, 2014. p. 19 e ss.

${ }_{29}$ Recorde-se que uma das tentativas de resposta às manifestações foi a tentativa de aproximação da sociedade civil com governo através do Plano Nacional de Participação Social. Posto em prática por meio do Decreto $n^{\circ}$ 8243/14 e BEÇAK, Rubens; LONGHI, João Victor Rozatti. O Parlamento e as reações à participação popular na sociedade informacional: a oportunidade do plano nacional de participação social (Decreto $\mathrm{n}^{\circ}$ 8.243/14) e o desafio dos projetos de decreto legislativo de sustação. In: Anais do XXII Congresso Nacional do CONPEDI - Florianópolis, 2014.

${ }^{30} \mathrm{Cf}$. BOBBIO, Norberto. O futuro da democracia: uma defesa das regras do jogo. Trad. de Marco Aurélio Nogueira. Rio de Janeiro: Paz e Terra, 1986. p. 66-67. Para maiores aprofundamentos, V. BECAK, Rubens; LONGHI, João Victor Rozatti. Tendencias da democracia participativa: a influência da Internet no perfil da representação e evento do orçamento participativo. In: Anais do XX Congresso Nacional do CONPEDI Conselho Nacional de Pesquisa e Pós-Graduacãa em Direito. (Vitória, 16-19. nov. 2011).

${ }_{31}$ Clara menção aqui a Habermas, HABERMAS, Jürgen. Direito e democracia: entre faticidade e validade. Trad, Flávio Breno Siebneichler. Rio de Janeiro: Tempo brasileiro, 1997. passim. Cláudio Pereira de Souza Neto subdivide duas visões de democracia deliberativa, a conceitual de Rawls e a procedimentalista de Habermas para delinear o que chama modelo cooperativo. Cf. SOUZA NETO, Cláudio Pereira de. Teoria constitucional e democracia deliberativa: um estudo sobre o papel do direito na garantia das condições para a cooperação na deliberação democrática. Rio de Janeiro: Renovar, 2006. p. 129. Para maiores aprofundamentos, $V$. BEÇAK, Rubens; LONGHI, João Victor Rozatti. Democracia deliberativa e ciberdemocracia: riscos e desafios para sua implementação. in Anais do XXII Encontro Nacional do CONPEDI / UNINOVE .13 a 16 de novembro de 2013. Universidade Nove de Julho - UNINOVE / São Paulo SP 
esgotamento. E que os mecanismos jurídicos hoje presentes como eleições periódicas, partidos políticos, representação política ou mesmo aqueles constitucionalmente eleitos, no caso brasileiro, para o exercício da soberania popular (plebiscito, referendo e iniciativa popular) tampouco parecem suficientes para concentrar esforços em prol de um processo de decisão política que ouça efetivamente estas vozes.

E o papel das tecnologias não é o de causa das revoltas mas de instrumento, veículo, de emancipação destas massas, que cada dia mais podem ter espaço para discutir, discordar, deliberar. Ainda que haja muitos desafios à implementação da ciberdemocracia em sua plenitude, a comunicação tem o condão de acelerar este processo.

No campo do Direito, cabe também às instituições (Parlamentos, Executivos, Judiciários, Funções essenciais à justiça, etc.) mostrarem-se dispostas a repensar a si próprias, suas funções e seus mecanismos de diálogo com a sociedade civil, seu modo de atuação, os interesses a que servem.

Orçamentos participativos virtuais, eletronic town meetings e tantas outras iniciativas já existem como tentativas de oxigenar os procedimentos de tomada de decisão política. E promover mais interação pela Internet entre cidadãos e seus representantes vai muito além de uma equipe de marketing pessoal gerindo uma conta no twitter do deputado, senador, prefeito ou presidente (candidato ou eleito). Passa pela assunção por parte das instituições de que é necessário um diálogo permanente com movimentos sociais, por vezes obrigando-se a seguir a vontade popular contra a de grupos de interesses sempre presentes no cotidiano dos Parlamentos e Executivos ao redor do planeta. Usar a tecnologia a favor de um processo democrático diferente do atual parece ser um caminho inexorável. Antes que as ruas falem por si oura vez.

\section{REFERÊNCIAS}

ANTUNES, Ricardo; BRAGA, Ruy. Os dias que abalaram o Brasil: as rebeliões de junho, julho de 2013. in Revista de políticas Públicas: programa de pós-graduação em políticas públicas da Universidade Federal do Maranhão. v. 18, n. 2 (2014).

BEÇAK, Rubens; LONGHI, João Victor Rozatti. Democracia deliberativa e ciberdemocracia: riscos e desafios para sua implementação. in Anais do XXII Encontro Nacional do CONPEDI / UNINOVE .13 a 16 de novembro de 2013. Universidade Nove de Julho - UNINOVE / São Paulo - SP 
BEÇAK, Rubens; LONGHI, João Victor Rozatti. Internet como esfera pública global e o papel atual dos parlamentos no processo legislativo. in Revista de Cultura e Extensão da USP, São Paulo, n. 13, p.43-53, maio 2015 DOI: http://dx.doi.org/10.11606/issn.2316-9060.v13i0p43-53. Acesso em: 15 set. 2015.

BEÇAK, Rubens; LONGHI, João Victor Rozatti. O Parlamento e as reações à participação popular na sociedade informacional: a oportunidade do plano nacional de participação social (Decreto $\mathrm{n}^{\circ}$ 8.243/14) e o desafio dos projetos de decreto legislativo de sustação. In: Anais do XXII Congresso Nacional do CONPEDI - Florianópolis, 2014.

BEÇAK, Rubens; LONGHI, João Victor Rozatti. Tendências da democracia participativa: a influência da Internet no perfil da representação e evento do orçamento participativo. In: Anais do XX Congresso Nacional do CONPEDI - Conselho Nacional de Pesquisa e Pós-Graduação em Direito. (Vitória, 16-19. nov. 2011).

BEÇAK, Rubens. Democracia: hegemonia e aperfeiçoamento. São Paulo: Saraiva, 2014.

BENKLER, Yochai. The wealth of networks: how social production transforms markets and freedom. New Heaven: Yale University Press, 2003.

BERNARDES, Maciele Berger. Democracia na Sociedade Informacional: o desenvolvimento da democracia digital nos municípios brasileiros. São Paulo: Saraiva, 2013.

BOBBIO, Norberto. O futuro da democracia: uma defesa das regras do jogo. Trad. de Marco Aurélio Nogueira. Rio de Janeiro: Paz e Terra, 1986.

BRASIL, Supremo Tribunal Federal. Ação Direta de Inconstitucionalidade 4650/DF, Relator(a): Min. Luis Fux, Tribunal Pleno, julgado em 16 e 17.9.2015.

CARNEIRO, Thiago Lopes. Da "imobilidade" à ação: por que os brasileiros saíram às ruas em junho de 2013? O contagion comportamento como parte da explicação. in E-Legis - Revista Eletrônica do Programa de Pós-Graduação da Câmara dos Deputados, [S.l.], p. 26-45, ago. 2014. ISSN 2175-0688. Disponível em: <http://e-legis.camara.leg.br/cefor/index.php/elegis/article/view/185/228>. Acesso em: 06 Out. 2015

CASTELLS, Manuel. La galaxia Internet. Trad. Raúl Quintana. Barcelona: Aretè, 2001.

CASTELLS, Manuel. Redes de indignação e esperança. Trad. Carlos Alberto Medeiros. Rio de Janeiro: Zahar, 2013.

EL-SHERIF, Ashraf. Egypt Post-Mubarak predicament. in Carnegie Endowment for International Peace. Carnegie Endowment for International Peace Publications Department: Washington (DC), 2014. 
GABRIEL, Mark A. Islam and Terrorism: The Truth About ISIS, the Middle East and Islamic Jihad. 2. ed. Crishma House: Florida, 2015.

HABERMAS, Jürgen. Direito e democracia: entre faticidade e validade. Trad, Flávio Breno Siebneichler. Rio de Janeiro: Tempo brasileiro, 1997.

KANDIL, Hazem. A revolta no Egito. Novos estudos - CEBRAP [online]. 2011, n. 91, pp. 155-193.

LEMOS, André; LEVY, Pierre. O futuro da Internet: em direção a uma ciberdemocracia planetária. São Paulo: Paulus, 2010.

LESSIG, Lawrence. Code: version 2.0. 2. ed. New York: Basic Books, 2006.

LYNCH, Mark. The Arab uprising: the unfinished revolutions of the middle East. New York: Public Affairs, 2013.

LYNCH, Mark. Voices of the New Arab Public: Iraq, al-Jazeera, and Middle East Politics Today. New York: Columbia University Press, 2010.

MAGRANI, Eduardo. Democracia conectada: a Internet como ferramenta de engajamento politico-democrático. Curitiba: Juruá, 2014.

MARICATO, Ermínio et alli. Cidades rebeldes - Passe Livre e as manifestações que tomaram as ruas no Brasil. São Paulo: Boitempo/Carta Maior, 2013.

MOROZOV, Evgeny. The net desilusion: the dark side of network freedom. New York: Public Affairs, 2011

NASCIMENTO, Paulo Cesar. Déspotas em retirada: entrevista com Arlene Clemesha, Mohamed Habib e Reginaldo Nasser, in Jornal da Unicampi. Campinas, 14 a 20 de março de 2011 - ANO XXV - N 486. p. 6-7. Disponível em :

http://www.unicamp.br/unicamp/unicamp_hoje/ju/marco2011/ju486_pag05.php. Acesso em: 01 out. 2015.

PARISER, Eli. O filtro invisível. O que a Internet está escondendo de você. Trad. Diego Alfaro. Rio de Janeiro: Zahar, 2012.

PEREZ LUÑO, António. ¿Ciberciudadanía o ciudadanía.com? Barcelona: Gedisa, 2004.

PRASHAD, Vijay. Arab Spring, Libyan Winter. Baltimore: AK Press Publishing \& Distribution, 2012. 
ISSN 1981-3694

(DOI): $10.5902 / 1981369420048$

REVISTA ELETRÔNICA DO CURSD DE

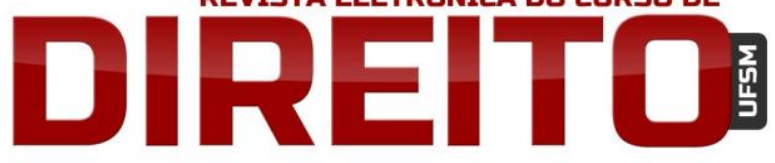

O PAPEL DAS TECNOLOGIAS DE COMUNICAÇÃO EM MANIFESTAÇÕES POPULARES: A “PRIMAVERA ÁRABE” E AS “JORNADAS DE JUNHO” NO BRASIL

RUTHERFORD, Bruce K. Egypt after Mubarak: Liberalism, Islam, and Democracy in the Arab World: Liberalism, Islam, and Democracy in the Arab World. Princeton: Princeton University Press, 2013.

SINGER, André. Brasil, junho de 2013: classes e ideologias cruzadas. Novos estud. - CEBRAP, São Paulo , n. 97, p. 23-40, Nov. 2013. Disponível em:

<http://www.scielo.br/scielo.php?script=sci_arttext\&pid=S0101-

$33002013000300003 \&$ lng=en\&nrm=iso>. access on 06 Out. 2015.

SOUZA NETO, Cláudio Pereira de. Teoria constitucional e democracia deliberativa: um estudo sobre o papel do direito na garantia das condições para a cooperação na deliberação democrática. Rio de Janeiro: Renovar, 2006.

SUNSTEIN, Cass. Republic.com 2.0. Princeton: Princeton University Press, 2007

WU, Tim. Impérios da comunicação. Do telefone à internet, da AT\&T ao Google. Trad. Cláudio Carina. Rio de Janeiro: Zahar, 2012. 